\section{Watermelon Production as Influenced by Lime, Gypsum, and Potassium}

\author{
S.J. Locascio and G.J. Hochmuth \\ Horticultural Sciences Department, University of Florida, Gainesville, FL 32611
}

Additional index words. Citrullus lanatus, plant nutrition, calcium

\begin{abstract}
Watermelon [Citrullus lanatus (Thunb.) Matsum. \& Nakai] were grown with three rates each of lime, gypsum, and K during two seasons to evaluate their effects on fruit production and mineral concentration. The first experimental site was a recently cleared Sparr fine sand with an initial water $\mathrm{pH}$ of 5.0 and Mehlich I extractable $\mathrm{K} \mathrm{of} 8 \mathrm{mg} \cdot \mathrm{kg}^{-1}$ (very low) and $20 \mathrm{mg} \cdot \mathrm{kg}^{-1} \mathrm{Ca}$ (very low). The second site was a virgin Pomona fine sand with a water $\mathrm{pH}$ of $4.8,28 \mathrm{mg} \cdot \mathrm{kg}^{-1} \mathrm{~K}$ (low), and $612 \mathrm{mg} \cdot \mathrm{kg}^{-1} \mathrm{Ca}$ (high). 'Crimson Sweet' fruit yields were reduced $10 \%$ with an increase in lime rate from 0 to $4.48 \mathrm{t} \cdot \mathrm{ha}^{-1}$ in the first season. In the second season, lime rate had no effect on yield. In both seasons, fruit yields were reduced $14 \%$ with an increase in Ca from gypsum from 0 to $1.12 \mathrm{t} \cdot \mathrm{ha}^{-1}$. On the soil testing very low in $\mathrm{K}$, yield increased with an increase in $\mathrm{K}$ rate from 90 to $224 \mathrm{~kg} \cdot \mathrm{ha}^{-1}$ with no lime or gypsum. On the soil testing low in $\mathrm{K}$, greatest yields were obtained with 90 $\mathrm{kg} \cdot \mathrm{ha}^{-1} \mathrm{~K}$ with no lime and gypsum. Application of lime and gypsum increased $\mathrm{Ca}$ and decreased $K$ in seedlings but not consistently in older leaf and fruit tissues. An increase in $K$ application increased leaf $K$ in the first season but not in the second. Fruit firmness and soluble solids content were not consistently affected by treatment during the two seasons. Thus, on soils low in toxic elements ( $\mathrm{Mn}$ and $\mathrm{Al}$ ) such as used in this study, watermelon will grow well and tolerate a wide range of soil $\mathrm{pH}$ values without additional $\mathrm{Ca}$ from lime or gypsum.
\end{abstract}

Watermelons are often produced on soils with very low $\mathrm{pH}$ values, low organic matter content, and low plant nutrient content. During the 1997-98 season in Florida, watermelon was produced on 13,000 ha with a value of \$60 million (Witzig and Pugh, 1999). On newly cleared "flatwoods" soils in Florida, such as Leon and Immokalee fine sands where $\mathrm{Al}$ and $\mathrm{Mn}$ are typically toxic, the $\mathrm{pH}$ may be as low as 3.5. On better drained soils, such as Lakeland fine sands, the soil $\mathrm{pH}$ is often 5.0 or higher. On very acidic soils, watermelon seeds will germinate but generally die before development of the second or third true leaves (Locascio et al., 1964). Increased crop growth in response to liming on very acidic soils is large (Everett et al., 1965; Sundstrom et al., 1983; Waters and Nettles, 1961). However, watermelons grown on unlimed soils where the $\mathrm{pH}$ is 5.5 or higher generally do not respond to lime (Locascio and Lundy, 1962). The effects of lime on watermelon growth when grown on soils with an intermediate $\mathrm{pH}$ of 5.0 are not well known. These latter soils may be quite high or very low in extractable $\mathrm{Ca}$. Additional $\mathrm{Ca}$ from gypsum applied on soils with a $\mathrm{pH}$ range from 5.4 to 5.7 resulted in reduced $\mathrm{K}$ uptake and reduced watermelon fruit yield (Sundstrom and Carter, 1983). The concentrations of native-soil $\mathrm{Ca}$ or applied $\mathrm{Ca}$ have been shown to have variable effects on the quality of watermelon fruit, but generally increase fruit $\mathrm{Ca}$ concentration and reduce blossom-end rot (Waters and Nettles, 1961).

Received for publication 5 Apr. 2001. Accepted for publication 11 Nov. 2001. This research was supported by the Florida Agricultural Experiment Station, and approved for publication as Journal Series No. R-08091.
Increased rind thickness and rupture pressure of the rind have been related to increased fruit Ca. Little information was found on the yield response of watermelon to $\mathrm{K}$ with various $\mathrm{Ca}$ rates supplied from lime and gypsum. In one study, application of high rates of K resulted in reduced plant absorption of native-soil $\mathrm{Ca}$ (Elmstrom et al., 1973). In previous studies with lime on watermelon, the effects of additional $\mathrm{Ca}$ on yield and fruit disorders were not separated from lime effects. Studies reported here were conducted to evaluate the effects of lime, $\mathrm{Ca}$ from gypsum, and $\mathrm{K}$ rate on watermelon grown on soils in the intermediate soil acidity $(\approx 5.0)$ range.

\section{Materials and Methods}

'Crimson Sweet' watermelons were grown on a virgin Sparr fine sand (loamy, siliceous, hyperthermic Grossarenic Paleudults) during the 1985 season and on a Pomona fine sand (sandy, siliceous, hyperthermic Ultic Haplaquods) during the 1986 season at the Univ. of Florida Horticultural Research Unit, Gainesville. The soil $\mathrm{pH}$ values in the two seasons were 5.0 and 4.7; Mehlich I extractable $\mathrm{K}$ values were $8 \mathrm{mg} \cdot \mathrm{kg}^{-1}$ (very low) and $28 \mathrm{mg} \cdot \mathrm{kg}^{-1}$ (low); and $\mathrm{Ca}$ values were 20 $\mathrm{mg} \cdot \mathrm{kg}^{-1}$ (very low) and $612 \mathrm{mg} \cdot \mathrm{kg}^{-1}$ (high), respectively. Treatments were factorial combinations of three $\mathrm{CaCO}_{3}$ rates $(0,2.24$ and $\left.4.48 \mathrm{t} \cdot \mathrm{ha}^{-1}\right)$; three Ca rates of $0,0.56$, and 1.12 $\mathrm{t} \cdot \mathrm{ha}^{-1}$ from gypsum $\left(0,2.85\right.$, and $5.70 \mathrm{t} \cdot \mathrm{ha}^{-1}$ gypsum); and three rates of $\mathrm{K}(90,157$, and $224 \mathrm{~kg} \cdot \mathrm{ha}^{-1}$ ) arranged in randomized complete-block design with four replications. Plots were $2.75 \mathrm{~m}$ wide and $12.2 \mathrm{~m}$ long. After the soil was disked in January of each season, gypsum and $\mathrm{CaCO}_{3}$ were broadcast, disked into the soil to a depth of $0.2 \mathrm{~m}$, and beds were made on 25 Feb. 1985 and on 7 Mar. 1986. Fertilizer was applied at the rate of 150-70$\mathrm{X}-50-50 \mathrm{~kg} \cdot \mathrm{ha}^{-1} \mathrm{~N}-\mathrm{P}-\mathrm{K}-\mathrm{Mg}-$ micronutrient mix, and $2.24 \mathrm{~kg} \cdot \mathrm{ha}^{-1} \mathrm{Cu}$. The fertilizer was formulated from ammonium nitrate, concentrated superphosphate, potassium chloride, magnesium sulfate, fritted micronutrient mix FTE 503 (Frit Industries, Ozark, Ala.), and copper sulfate. One-half of the $\mathrm{N}$ and $\mathrm{K}$ and $100 \%$ of the $\mathrm{P}, \mathrm{Mg}$, and micronutrients were broadcast in the bed area $(1 \mathrm{~m})$ when the beds were reestablished on 11 Mar. 1985 and 18 Mar. 1986. 'Crimson Sweet' seeds were planted in hills spaced $0.75 \mathrm{~m}$ apart immediately after beds were formed. Five weeks after seeding, the second application of $\mathrm{N}$ and $\mathrm{K}$ was applied in 0.3-m-wide broad bands on each bed shoulder. Overhead sprinkler irrigation was supplied to supplement rainfall.

Plants were thinned to one per hill and removed plants were taken for dry-weight determination and mineral analysis on $10 \mathrm{Apr}$. 1985. Mature leaves were also sampled for analysis on 13 June 1985 and on 22 Apr. 1986. Marketable fruits were harvested on 20 June 1985 and on 1 and 14 July 1986. Fruit samples were taken for soluble solids determination, mineral analysis, and for fruit firmness determinations in 1986. Total soluble solids content was determined from an aliquot of juice obtained from the heart section of the fruit with a refractometer (Abbe, Atago Co., Tokyo). Fruit firmness was determined on the whole fruit in the middle area of the fruit with a firmness testing instrument (Chatillon Model HTCM, John Chatillon and Sons, Jamaica, N.Y.). For mineral analysis, tissue was taken from the heart area, oven-dried, and a 0.5 -g sample was ashed at $550{ }^{\circ} \mathrm{C}$. Total $\mathrm{N}$ was determined by micro-Kjeldahl, $\mathrm{P}$ colorimetrically, $\mathrm{K}$ by flame emission spectroscopy, and $\mathrm{Ca}$ and $\mathrm{Mg}$ by atomic absorption (Rhue and Kidder, 1984). Data were statistically analyzed by analysis of variance.

\section{Results and Discussion}

Watermelon fruit yields were affected by a four-way interaction of year, lime, gypsum, and K rates (Fig. 1). In 1985 on the soil testing very low in $\mathrm{K}$, fruit yield increased with an increase in $\mathrm{K}$ rate from 90 to $224 \mathrm{~kg} \cdot \mathrm{ha}^{-1}$ only with the 0 lime and 0 and $2.85 \mathrm{t} \cdot \mathrm{ha}^{-1}$ gypsum. With higher rates of lime, an increase in $\mathrm{K}$ rate did not result in an increase in yield. In 1986 on a soil testing low in K (Fig. 1), fruit yields increased with an increase in $\mathrm{K}$ rate from 90 to $157 \mathrm{~kg} \cdot \mathrm{ha}^{-1}$ only at the $2.24 \mathrm{t} \cdot \mathrm{ha}^{-1}$ lime rate with the 0 and $2.85 \mathrm{t} \cdot \mathrm{ha}^{-1}$ gypsum rates. However, equal yields were obtained with 0 lime and gypsum with $\mathrm{K}$ at 90 and $157 \mathrm{~kg} \cdot \mathrm{ha}^{-1}$. At the $4.48 \mathrm{t} \cdot \mathrm{ha}^{-1}$ lime rate and 0 gypsum rate, yields were reduced with an increase in $\mathrm{K}$ rate from 90 to $157 \mathrm{~kg} \cdot \mathrm{ha}^{-1}$.

These data indicate that in two seasons, watermelon did not respond with an increase in yield with the application of lime on soils with initial pHs of 5.0 and 4.8. Watermelon yields were similar with lime applications of 0 to $4.48 \mathrm{t} \cdot \mathrm{ha}^{-1}$. Application of gypsum resulted 


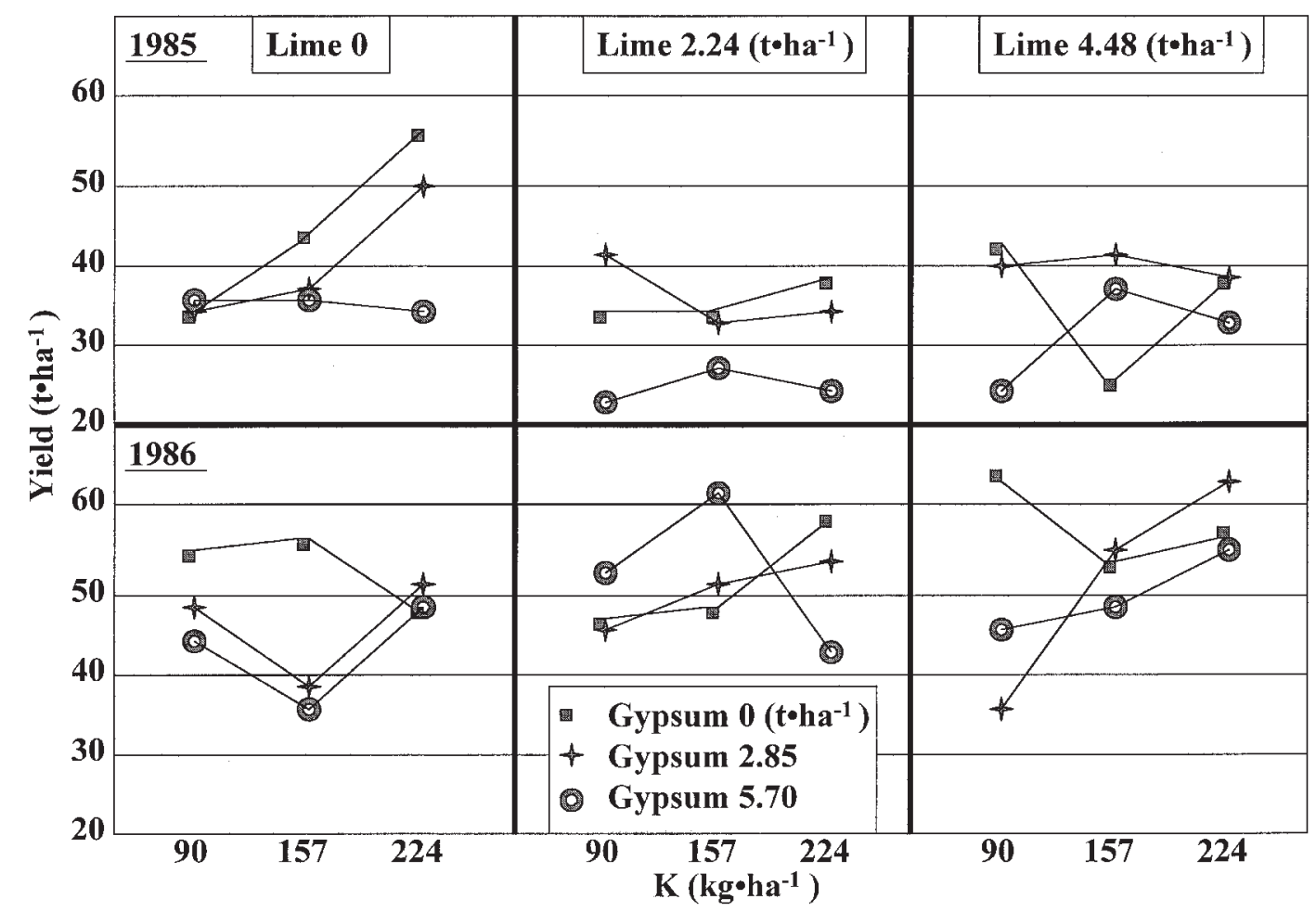

Fig. 1. Four-way interactions of lime rates $\left(0,2.24\right.$, and $\left.4.48 \mathrm{t} \cdot \mathrm{ha}^{-1}\right)$, gypsum rates $\left(0,2.85\right.$, and $\left.5.70 \mathrm{t} \cdot \mathrm{ha} \mathrm{a}^{-1}\right)$, and $\mathrm{K}$ rates $\left(90,157\right.$, and $224 \mathrm{~kg} \cdot$ ha $\left.\mathrm{a}^{-1}\right)$ on watermelon fruit yields in 1985 (top) and 1986 (bottom). In 1985, an orthogonal comparison of lime rate linear $\times$ gypsum rate linear $\times$ potassium rate linear was significant $(P \leq 0.05)$. In 1986 , lime rate quadratic $\times$ gypsum rate linear $\times$ potassium rate linear was significant $(P \leq 0.05)$.

in an overall reduction in yield of $\approx 17 \%$ during the two seasons. Sundstrom and Carter (1983) reported that increased rates of $\mathrm{Ca}$ from gypsum resulted in reduced watermelon yield and tissue $\mathrm{K}$ concentration. As gypsum rate increased from 0 and $5.70 \mathrm{t} \cdot \mathrm{ha}^{-1}$, extractable $\mathrm{SO}_{4}$ increased linearly from 10 to $164 \mathrm{mg} \cdot \mathrm{kg}^{-1}$ (data not shown) and this increase in soluble salts probably resulted in reduced yields.

Dry weights of 1-month-old seedlings sampled on 10 Apr. 1985 were increased from 0.30 to $0.35 \mathrm{~g}$ per plant by an increase in lime rate from 0 to $2.24 \mathrm{t} \cdot \mathrm{ha}^{-1}$ (Table 1 ). A further increase in lime rate to $4.48 \mathrm{t} \cdot \mathrm{ha}^{-1}$ resulted in a reduction in seedling dry weight to $0.32 \mathrm{~g}$. An increase in application of gypsum from 0 to $5.7 \mathrm{t} \cdot \mathrm{ha}^{-1}$ resulted in a linear decrease in seedling dry weight from 0.34 to $0.30 \mathrm{~g}$. Application of $\mathrm{K}$ rates from 90 to $224 \mathrm{~kg} \cdot \mathrm{ha}^{-1}$ had no effect on seedling dry weight. Seedling concentration of $\mathrm{K}$ decreased linearly with an increase in lime and gypsum rates, but $\mathrm{K}$ concentration increased with an increase in $\mathrm{K}$ rate. In contrast, tissue $\mathrm{Ca}$ concentration increased with lime and gypsum application and decreased in response to an increase in $\mathrm{K}$ application. Elmstrom et al. (1973) also found that increased rates of $\mathrm{K}$ reduced tissue $\mathrm{Ca}$. The range of $\mathrm{K}$ concentrations in seedlings was 43.8 to $52.5 \mathrm{~g} \cdot \mathrm{kg}^{-1}$ and Ca ranged from 18.2 to $31.1 \mathrm{~g} \cdot \mathrm{kg}^{-1}$. Leaf tissues at the end of the season were lower in $\mathrm{K}$ and higher in $\mathrm{Ca}$ (Table 2) than the above seedling concentrations (Table 1) in 1985. Leaf tissue K concentrations on 13 June 1985 (Table 2) were increased linearly from 10 to $>12 \mathrm{~g} \cdot \mathrm{kg}^{-1}$ with an increase in both lime and $\mathrm{K}$ rates. Tissue $\mathrm{Ca}$ concentration ranged from 29.7 to $31.3 \mathrm{~g} \cdot \mathrm{kg}^{-1}$
Table 1. Main effects of lime, gypsum, and $\mathrm{K}$ rate on seedling dry weight and $\mathrm{K}$ and Ca concentrations of plants sampled on 10 April 1985.

\begin{tabular}{|c|c|c|c|}
\hline \multirow{3}{*}{$\begin{array}{l}\text { Treatment } \\
\left(\mathrm{t} \cdot \mathrm{ha}^{-1}\right)\end{array}$} & \multicolumn{3}{|c|}{ Seedling } \\
\hline & \multirow{2}{*}{$\begin{array}{l}\text { Dry wt } \\
\text { (g/plant) }\end{array}$} & \multicolumn{2}{|c|}{ Concn $\left(\mathrm{g} \cdot \mathrm{kg}^{-1}\right)$} \\
\hline & & $\mathrm{K}$ & $\mathrm{Ca}$ \\
\hline \multicolumn{4}{|l|}{ Lime } \\
\hline 0 & 0.30 & 50.8 & 18.2 \\
\hline 2.24 & 0.35 & 49.1 & 27.8 \\
\hline \multirow[t]{2}{*}{4.48} & 0.32 & 45.4 & 31.1 \\
\hline & $\mathrm{Q}^{* *}$ & $\mathrm{~L}^{* *}$ & $\mathrm{Q}^{* * *}$ \\
\hline \multicolumn{4}{|l|}{ Gypsum } \\
\hline 0 & 0.34 & 52.2 & 20.6 \\
\hline 2.85 & 0.33 & 49.4 & 27.0 \\
\hline \multirow[t]{2}{*}{5.70} & 0.30 & 43.8 & 29.6 \\
\hline & $\mathrm{L}^{* *}$ & $\mathrm{~L}^{* *}$ & $\mathrm{Q}^{* *}$ \\
\hline
\end{tabular}

Potassium

$\underline{\left(\mathrm{kg} \cdot \mathrm{ha}^{-1}\right)}$

\begin{tabular}{cccc}
\hline 90 & 0.32 & 44.4 & 27.1 \\
157 & 0.33 & 48.5 & 25.5 \\
224 & 0.33 & 52.5 & 24.6 \\
& NS & L $^{* *}$ & L $^{* *}$
\end{tabular}

Ns, *** Nonsignificant or significant at $P \leq 0.01$; significant effects were linear (L) or quadratic (Q).

but was not affected by treatment. Fruit tissue $\mathrm{K}$ concentrations were not influenced by lime and gypsum rate but increased linearly from 17.5 to $19.9 \mathrm{~g} \cdot \mathrm{kg}^{-1}$ with an increase in $\mathrm{K}$ rate from 90 to $224 \mathrm{~kg} \cdot \mathrm{ha}^{-1}$. Fruit tissue Ca concentrations increased from 15 to $18.9 \mathrm{~g} \cdot \mathrm{kg}^{-1}$ with an increase in lime rate from 0 to $2.24 \mathrm{t} \cdot \mathrm{ha}^{-1}$, but then decreased to $16.2 \mathrm{~g} \cdot \mathrm{kg}^{-1}$ with a further increase in lime to $4.48 \mathrm{t} \cdot \mathrm{ha}^{-1}$. Fruit tissue $\mathrm{Ca}$ concentrations also increased linearly from 13.9 to $18.5 \mathrm{~g} \cdot \mathrm{kg}^{-1}$ with an increase in gypsum rate from 0 to $5.7 \mathrm{t} \cdot \mathrm{ha}^{-1}$. In the second season (Table 3), leaf tissue samples taken early in the
Table 2. Main effects of lime, gypsum, and $\mathrm{K}$ rate on leaf tissue and fruit $\mathrm{K}$ and $\mathrm{Ca}$ concentrations in 1985.

\begin{tabular}{|c|c|c|c|c|}
\hline \multirow{3}{*}{$\begin{array}{l}\text { Treatment } \\
\left(\mathrm{t} \cdot \mathrm{ha}^{-1}\right)\end{array}$} & \multicolumn{4}{|c|}{ Concn $\left(\mathrm{g} \cdot \mathrm{kg}^{-1}\right)$} \\
\hline & \multicolumn{2}{|c|}{$\begin{array}{c}\text { Leaf } \\
\text { 13 June } 1985 \\
\end{array}$} & \multicolumn{2}{|c|}{$\begin{array}{c}\text { Fruit } \\
\text { 20 June } 1985 \\
\end{array}$} \\
\hline & $\mathrm{K}$ & $\mathrm{Ca}$ & $\mathrm{K}$ & $\mathrm{Ca}$ \\
\hline \multicolumn{5}{|l|}{ Lime } \\
\hline 0 & 10.4 & 29.7 & 19.6 & 15.0 \\
\hline 2.24 & 11.8 & 30.6 & 18.7 & 18.9 \\
\hline \multirow[t]{2}{*}{4.48} & 12.4 & 31.3 & 18.2 & 16.2 \\
\hline & $\mathrm{L}^{*}$ & NS & NS & $\mathrm{Q}^{* *}$ \\
\hline \multicolumn{5}{|l|}{ Gypsum } \\
\hline 0 & 11.1 & 31.4 & 18.7 & 13.9 \\
\hline 2.85 & 12.1 & 30.6 & 18.8 & 17.7 \\
\hline \multirow[t]{2}{*}{5.70} & 11.5 & 29.5 & 19.0 & 18.5 \\
\hline & NS & NS & NS & $\mathrm{L}^{*}$ \\
\hline \multicolumn{5}{|l|}{$\begin{array}{l}\text { Potassium } \\
\left(\mathrm{kg} \cdot \mathrm{ha}^{-1}\right)\end{array}$} \\
\hline 90 & 10.1 & 32.2 & 17.5 & 16.0 \\
\hline 157 & 12.1 & 29.5 & 19.1 & 17.1 \\
\hline \multirow[t]{2}{*}{224} & 12.6 & 29.9 & 19.9 & 17.0 \\
\hline & $\mathrm{L}^{* *}$ & NS & $\mathrm{L}^{* *}$ & NS \\
\hline
\end{tabular}

Ns, *,**Nonsignificant or significant at $P \leq 0.05$ or 0.01 , respectively; significant effects were linear (L) or quadratic $(\mathrm{Q})$.

season (22 Apr. 1986) indicated that K concentration was not affected by lime or K rates. With an increase in gypsum application from 0 to $2.85 \mathrm{t} \cdot \mathrm{ha}^{-1}$, leaf $\mathrm{K}$ concentration was decreased from 47.4 to $35.4 \mathrm{~g} \cdot \mathrm{kg}^{-1}$. With an increase in lime rate, leaf tissue Ca concentration increased linearly; however, no response to gypsum or $\mathrm{K}$ rate was observed. Leaf tissue concentrations of $\mathrm{K}$ and $\mathrm{Ca}$ all were considered to be within the adequate range (Locascio, 1993). 
Table 3. Main effects of lime, gypsum, and $\mathrm{K}$ rate on leaf $\mathrm{K}$ and $\mathrm{Ca}$ concentrations, fruit firmness, and fruit soluble solids content in 1986 .

\begin{tabular}{|c|c|c|c|c|c|c|}
\hline \multirow{2}{*}{$\begin{array}{l}\text { Treatment } \\
\left(\mathrm{t} \cdot \mathrm{ha}^{-1}\right)\end{array}$} & \multicolumn{2}{|c|}{$\begin{array}{c}\text { Leaf concn, } 22 \text { Apr. } 1986 \\
\left(\mathrm{~g} \cdot \mathrm{kg}^{-1}\right)\end{array}$} & \multicolumn{2}{|c|}{$\begin{array}{l}\text { Fruit firmness } \\
(\mathrm{N})\end{array}$} & \multicolumn{2}{|c|}{$\begin{array}{l}\text { Fruit soluble solids } \\
(\%)\end{array}$} \\
\hline & $\mathrm{K}$ & $\mathrm{Ca}$ & 1 July 1986 & 14 July 1986 & 1 July 1986 & 14 July 1986 \\
\hline \multicolumn{7}{|l|}{ Lime } \\
\hline 0 & 31.0 & 12.4 & 5.77 & 5.89 & 10.7 & 10.8 \\
\hline 2.24 & 43.5 & 20.7 & 5.45 & 5.84 & 10.9 & 10.9 \\
\hline \multirow{2}{*}{4.48} & 48.6 & 26.3 & 5.89 & 5.78 & 11.0 & 10.8 \\
\hline & NS & $\mathrm{L}^{* *}$ & NS & NS & NS & NS \\
\hline \multicolumn{7}{|l|}{ Gypsum } \\
\hline 0 & 47.4 & 20.0 & 6.27 & 6.04 & 10.6 & 10.7 \\
\hline 2.85 & 35.4 & 20.0 & 5.42 & 5.93 & 11.0 & 10.6 \\
\hline \multirow[t]{2}{*}{5.70} & 40.4 & 19.4 & 5.41 & 5.54 & 10.9 & 11.1 \\
\hline & $\mathrm{Q}^{*}$ & NS & $\mathrm{L}^{*}$ & NS & NS & NS \\
\hline \multicolumn{7}{|l|}{$\begin{array}{l}\text { Potassium } \\
\left(\mathrm{kg} \cdot \mathrm{ha}^{-1}\right)\end{array}$} \\
\hline 90 & 36.3 & 20.3 & 5.89 & 6.08 & 10.6 & 10.4 \\
\hline 157 & 44.1 & 20.4 & 5.30 & 5.71 & 11.0 & 11.0 \\
\hline \multirow[t]{2}{*}{224} & 42.8 & 18.8 & 5.01 & 5.72 & 11.0 & 11.0 \\
\hline & NS & NS & $\mathrm{Q}^{*}$ & NS & NS & $\mathrm{L}^{*}$ \\
\hline
\end{tabular}

quadratic $(\mathrm{Q})$.

Fruit firmness was influenced by gypsum and $\mathrm{K}$ rates at the first harvest but not the second (Table 3). At the 1 July harvest, fruit firmness was decreased slightly by an increase in gypsum and $\mathrm{K}$ rates. Treatment had little effect on fruit tissue soluble solids at both sampling dates, which is consistent with the results of Scott et al. (1993).

Watermelon response to lime and gypsum was negligible on these two soils even though the soil $\mathrm{pH}$ was 4.7 to 5.0 and soil $\mathrm{Ca}$ was 20 and 612 ppm in the two seasons, respectively. Although seedling tissue Ca increased with $\mathrm{Ca}$ application, seedling $\mathrm{K}$ and fruit yields were reduced with application of lime and gypsum. Detrimental effects of low $\mathrm{pH}$ on growth is often associated with increased uptake of Mn (Sundstrom et al., 1983) and Al (Fiskell et al., 1964). Fiskell et al. (1964) found that a lack of response to lime on soils with low $\mathrm{pH}$ was associated with a reduced $\mathrm{Al}$ concentration in the leaf tissue. Thus, on soils low in toxic elements ( $\mathrm{Mn}$ and $\mathrm{Al}$ ) such as used in this study, watermelon will grow well and tolerate a wide range of soil $\mathrm{pH}$ values as previously shown (Locascio et al., 1970), without additional Ca from lime or gypsum. On a soil testing very low in $\mathrm{K}$, the $\mathrm{K}$ requirement was $224 \mathrm{~kg} \cdot \mathrm{ha}^{-1}$ even though $125 \mathrm{~kg} \cdot \mathrm{ha}^{-1}$ was recommended according to soil test results (Hochmuth and Hanlon, 2000). On the soil testing low in $\mathrm{K}, 112 \mathrm{~kg} \cdot \mathrm{ha}^{-1}$ was recommended and was adequate.

\section{Literature Cited}

Elmstrom, G.W., J.G.A. Fiskell, and F.G. Martin. 1973. Nutrient distribution in soil and watermelon plant uptake: Effect of fertilizer timing, rate, and placement. Soil and Crop Sci. Soc. Fla. Proc. 32:154-158.
Everett, P.H., S.J. Locascio, and J.G. Fiskell. 1965. Factors involved in liming soil for watermelon production. Proc. Fla. State Hort. Soc. 78:177-182.

Fiskell, J.G.A., S.J. Locascio, H.L. Breland, and T.L. Yuan. 1964. Effects of soil acidity and liming of Leon fine sand on the exchange properties and on watermelons as indicator plants. Soil and Crop Sci. Soc. Fla. Proc. 24:52-63.

Hochmuth, G.J. and E.A. Hanlon. 2000. Standardized fertilization recommendations for vegetable crops. Fla. Coop. Ext. Serv. Cir. 1152.

Locascio, S.J. 1993. Cucurbits: Cucumber, muskmelon, and watermelon, p. 123-130. In: W.F. Bennett. Nutrient deficiencies and toxicities in crop plants. Amer. Phytopathol. Soc., St. Paul, Minn.

Locascio, S.J., P.H. Everett, and J.G. Fiskell. 1964 Copper as a factor in watermelon fertilization. Proc. Fla. State Hort. Soc. 77:190-194.

Locascio, S.J., J.G.A. Fiskell, and P.H. Everett. 1970. Advances in watermelon fertility. Proc. Trop. Reg. Amer. Soc. Hort. Sci. 14:223-231.

Locascio, S.J. and H.W. Lundy. 1962. Lime and minor element studies with watermelon. Proc. Fla. State Hort. Soc. 75:131-136.

Rhue, R.D. and G. Kidder. 1984. Procedures used by the IFAS Extension soil testing laboratory and interpretation of results. Fla. Agr. Coop. Ext. Ser. Circ. 596

Scott, W.D., B.D. McCraw, J.E. Motes, and M.W. Smith. 1993. Application of calcium to soil and cultivar affect elemental concentration of watermelon leaf and rind tissue. J. Amer. Soc. Hort. Sci. 118:201-206.

Sundstrom, F.J. and S.J. Carter. 1983. Influence of $\mathrm{K}$ and $\mathrm{Ca}$ on quality and yield of watermelon. J. Amer Soc. Hort Sci. 108:879-881.

Sundstrom, F.J., R.L. Edwards, R.J. Constantin, and D.W. Wells. 1983. Influence of soil acidity on watermelon leaf tissue mineral concentration and yield. J. Amer Soc. Hort Sci. 108:734-736.

Waters, W.E. and V.F. Nettles. 1961. The influence of hydrated lime, and nitrogen on the yield, quality, and chemical composition of Charleston Gray watermelon. Proc. Amer. Soc. Hort. Sci. 77:503-507.

Witzig, J.D. and N.L. Pugh. 1999. Florida agricultural statistics. Vegetable summary 1997-98. Fla. Agr. Stat. Serv., Orlando. 